\title{
The Case for Express Compulsory Mediation in England ANd Wales
}

\author{
Mercy Milgo*
}

\begin{abstract}
The current official position on compulsory mediation in England and Wales is that the courts cannot compel parties to mediate, but can impose cost sanctions on those who unreasonably refuse to mediate. Nevertheless, the English courts have ordered parties to mediate. Additionally, the courts' inconsistency on when a party's refusal to mediate will be deemed unreasonable has arguably created a body of divergent case law. This article argues that express compulsory mediation should be introduced in the English civil justice system to remedy the existing state of uncertainty. In particular, it is suggested that the English Civil Procedure Rules should be amended to introduce clear rules similar to the Australian provisions on mediation, which expressly authorise the courts to compel parties to mediate where appropriate. Such an approach would confirm the courts' powers and thereby avoid parties and their lawyers "guessing" whether a court will order them to mediate.
\end{abstract}

\section{A. INTRODUCTION}

Although mediation may be defined in different ways, the standard definition often adopted is that provided by the Centre for Effective Dispute Resolution (CEDR). The CEDR is one of the leading Alternative Dispute Resolution (ADR) service providers in England and Wales. ${ }^{1}$ It defines mediation as 'a flexible process conducted confidentially in which a neutral person actively assists parties in working towards a negotiated agreement of a dispute or difference, with the parties in ultimate control of the decision to settle and the terms of resolution.' ${ }^{2}$ The use of mediation to solve civil disputes in England and Wales is currently a common and growing practice. ${ }^{3}$ The growing use of mediation has resulted in a debate regarding compulsion. Although the present official position is that the courts in England and Wales do not have the power to compel parties to mediate, the exercise of that power by some courts has resulted in a state of uncertainty particularly for litigants and lawyers. As De Girolamo neatly

\footnotetext{
${ }^{*}$ LLB (Hons), LLM, BCL (Oxon). Legal Assistant at Keating Chambers and Future Pupil Barrister (Commercial Bar).

${ }^{1}$ Susan Blake, Julie Browne and Stuart Sime, A Practical Approach to Alternative Dispute Resolution (5th edn, Oxford University Press 2018) 224.

2 CEDR, 'Glossary of terms' CEDR < https://www.cedr.com/about_us/library/glossary.php > accessed 6 August 2019.

${ }^{3}$ Leonardo V.P. de Oliveira and Carolyn Beckwith, 'Is there a need to regulate mediation? The English and Welsh case study’ (2016) 42 Commonwealth Law Bulletin 327.
}

(C) 2021, The Authors. This is an open access article distributed under the terms of the Creative Commons Attribution License (CC BY) 4.0 https://creativecommons.org/licenses/by/4.0/, which permits unrestricted use, distribution and reproduction in any medium, provided the original author and source are credited. DOI: https://doi.org/10.14324/111.444.2052-1871.1204. 
puts it, "currently it is not clear where England and Wales stand on the issue of compulsion and mediation'. ${ }^{4}$

This article seeks to argue that mediation should be made expressly compulsory for civil disputes in England and Wales to clear up the uncertainty on whether the courts have the power to compel parties to mediate and when a party's refusal to mediate will be found unreasonable. Past and recent landmark cases dealing with compulsion and a party's refusal to mediate were analysed to reveal the uncertainty caused by diverging judicial decisions. Additionally, a detailed review of published literature by leading authors in the field and government reports was conducted.

The focus of this article is not on the advantages and disadvantages of mediation but rather on the need for clarity for litigants and lawyers on compulsory mediation in England and Wales. In regard to scope, this article focuses on civil disputes outside the family and employment law contexts.

Part B of the article discusses major civil justice reforms that sparked the growth of mediation in England and Wales. Part C analyses landmark decisions on compulsory mediation to illustrate the uncertainty caused by the judiciary. Part D analyses key cases dealing with a party's refusal to mediate to also reveal diverging judicial stances. Part E responds to the main arguments commonly put forward by critics of compulsory mediation. Part F proposes a framework of effectively integrating express compulsory mediation into the English civil justice system.

\section{B. THE CIVIL JUSTICE REFORMS ON COMPULSORY MEDIATION}

'The contemporary development of civil mediation in the United Kingdom can be traced back to 1994 when Lord Woolf was appointed to review the rules and procedures of the civil courts in England and Wales'. ${ }^{5}$ The primary aim of the review was to improve access to justice and reduce costs. ${ }^{6}$ After conducting the review, Lord Woolf recommended the use of ADR including mediation in his 1995 Access to Justice Interim Report and stated that ' ... in deciding on the future conduct of a case, the judge should be able to take into account the litigants

\footnotetext{
${ }^{4}$ Debbie De Girolamo, 'Rhetoric and civil justice: a commentary on the promotion of mediation without conviction in England and Wales’ (2016) 35 (2) Civil Justice Quarterly 162, 163.

5 Shahla F. Ali, Court Mediation Reform Efficiency, Confidence and Perceptions of Justice (Edward Elgar Publishing 2018) 66.

${ }^{6}$ Barbara Billingsley and Masood Ahmed, 'Evolution, revolution and culture shift: A critical analysis of compulsory ADR in England and Canada' (2016) 45 Common Law World Review 1, 4.
} 
unreasonable refusal to attempt ADR ${ }^{7}$ However, Lord Woolf did not recommend compulsory mediation on the basis that it would interfere with a citizen's constitutional right to access the courts. ${ }^{8}$

In his 1996 Access to Justice Final Report, Lord Woolf further encouraged the use of mediation for civil disputes and stressed on the practical advantages of mediation such as lower costs and a quicker resolution of disputes. ${ }^{9}$ However, he adhered to his earlier stance and did not recommend compulsory mediation in his final report. 'Despite his reluctance to introduce compulsory ADR, Lord Woolf did nevertheless enhance the role of ADR within the court process'. ${ }^{10}$ This is because by proposing that 'mediation be permanently embedded in the Civil Procedure Rules', ${ }^{11}$ Lord Woolf fostered the use of mediation for civil disputes.

Ten years after the Woolf reforms were implemented through the Civil Procedure Rules (CPR) 1998, Jackson LJ conducted a review of civil litigation costs. The aim of the Jackson review was to 'promote access to justice at proportionate cost'. ${ }^{12}$ Although Jackson LJ highlighted the benefits of mediation such as saving costs, he rejected the notion of compulsory mediation and stated that 'no-one should be forced to mediate'. ${ }^{13}$

The third major civil justice reform was the Briggs review conducted by Briggs LJ on the conduct of business in the Chancery Division of the High Court. Similar to Lord Woolf and Jackson LJ, Briggs LJ rejected compulsory mediation and emphasised that ADR is voluntary in nature and the court's role is limited to encouraging and assisting parties to settle. ${ }^{14}$

\section{JUDICIAL UNCERTAINTY ON COMPULSORY MEDIATION}

\footnotetext{
${ }^{7}$ Lord Woolf, 'Access to Justice: Interim Report to the Lord Chancellor on the Civil Justice System in England and Wales National Archives'

<https://webarchive.nationalarchives.gov.uk/20060213222829/http://www.dca.gov.uk/civil/interfr.htm> accessed 2 August 2019.

8 ibid.

${ }^{9}$ Lord Woolf, 'Access to Justice: Final Report to the Lord Chancellor on the Civil Justice System in England and Wales National Archives'

<https://webarchive.nationalarchives.gov.uk/20060213222829/http://www.dca.gov.uk/civil/interfr.htm> accessed 2 August 2019.

${ }^{10}$ Billingsley and Ahmed (n 6) 4.

11 Jane Player, 'Mediation of Corporate Disputes in UK' (2017) 14 European Company Law Journal 104, 104.

12 Lord Justice Jackson, Review of Civil Litigations Costs: Preliminary Report (Lord Justice Jackson May 2009) $\mathrm{v}$.

${ }^{13}$ Lord Justice Jackson, Review of Civil Litigations Costs: Final Report (Lord Justice Jackson December 2009) 262.

${ }^{14}$ Lord Justice Briggs, Chancery Modernisation Review: Final Report (Lord Justice Briggs December 2013$) 70$.
} 
Although the reforms expressly rejected compulsory mediation, the same cannot be said of judicial approaches in England and Wales. ${ }^{15}$ As Ahmed neatly puts it, 'The exercise by some members of the judiciary of their powers to compel parties to ADR in some cases has created unpredictability and a great deal of uncertainty for all participants in the civil court process, including judges, lawyers and, most importantly, the parties'. ${ }^{16}$ It is argued that the absence of a formal rule expressly authorising the courts to compel parties to mediate has resulted in a civil justice system where 'parties do not know where they stand'.${ }^{17}$ The analysis below of past and recent landmark decisions reveals the judicial inconsistency.

Shirayama Shokusan Co Ltd and others v Danovo Ltd is illustrative of the judiciary's initial stance on compulsory mediation in the period following the Woolf reforms. ${ }^{18}$ Shirayama concerned a dispute between leasehold owners where one of the parties applied to the court for an order requiring the dispute to be mediated. In granting the application, Blackburne $\mathrm{J}$ stated that 'the court does have jurisdiction to direct ADR even though one party may not be willing to have the dispute submitted to ADR' ${ }^{19}$ Citing the previous case of Kinstreet Ltd $v$ Balmargo Corpn Ltd in which the court ordered parties to mediate despite one party being unwilling to do so, ${ }^{20}$ Blackburne $\mathrm{J}$ stated that a court ordering parties to mediate is simply exercising its powers under rule 1.1 of the CPR which provides that the court must further the overriding objective of dealing with cases justly by actively managing cases. ${ }^{21}$ Blackburne $\mathrm{J}$ added that 'the exercise of those powers is not confined simply to the case where the parties jointly wish to settle the whole or part of the case or to use alternative dispute resolution procedures. There is nothing binding on this court to the effect that there is no jurisdiction, to have recourse to those powers unless both parties are willing'. ${ }^{22}$ Accordingly, despite the Woolf reforms expressly rejecting compulsory mediation, the cases that immediately followed such as Shirayama and Kinstreet, 'indicated that the courts could (and should) compel mediation'. ${ }^{23}$ However, a mere five months after Shirayama, the Court of Appeal in Halsey v Milton Keynes General NHS Trust strongly rejected compulsory mediation. ${ }^{24}$

\footnotetext{
${ }^{15}$ Billingsley and Ahmed (n 6) 8.

16 ibid 18.

17 ibid 6.

18 [2003] EWHC 3006 (Ch) (Shirayama).

${ }^{19}$ ibid [17] (Blackburne J).

${ }^{20}$ [2000] CP Rep Ch D 62.

${ }^{21}$ Shirayama (n 18) [18] and [19].

22 ibid.

${ }^{23}$ Gary Meggitt, 'PGF II SA v OMFS Co and compulsory mediation' (2014) 33 Civil Justice Quarterly 335, 335.

${ }^{24}$ [2004] EWCA (Civ) 576; [2004] 1 WLR 3002 (Halsey).
} 
Halsey concerned separate personal injury actions against two defendants in which the main question for the court was "when should the court impose a costs sanction against a successful litigant on the grounds that he has refused to take part in an alternative dispute resolution (“ADR")?' 25 In answering that question, Dyson LJ dealt with the issue of compulsion and stated that:

It is one thing to encourage the parties to agree to mediation, even to encourage them in the strongest terms. It is another to order them to do so. It seems to us that to oblige truly unwilling parties to refer their disputes to mediation would be to impose an unacceptable obstruction on their right of access to the court. ${ }^{26}$

Therefore, the court's stance in Halsey was that the 'court's role is to encourage, not to compel' parties to mediate. ${ }^{27}$ According to Halsey, the strongest form of encouragement lies in an ADR order made in the Admiralty and Commercial Court in the form set out in Appendix 7 to the Guide. ${ }^{28}$ Such an order requires parties to: exchange lists of neutrals or individuals who are available to conduct the ADR procedure, endeavour in good faith to agree a neutral individual or panel, take such serious steps as they may be advised to resolve their disputes and if the case is not settled, inform the court what steps towards ADR were taken and why such steps failed. ${ }^{29}$

It is argued that Halsey created uncertainty and confusion regarding compulsory mediation in two ways. First, Dyson LJ in Halsey deviated from the court's stance in Shirayama by stating that 'if the parties (or at least one of them) remain intransigently opposed to ADR, then it would be wrong for the court to compel them to embrace it'. ${ }^{30}$ Furthermore, Dyson LJ did not consider Shirayama when commenting on compulsion despite the fact that Shirayama dealt precisely with that issue; ${ }^{31}$ although the Court of Appeal was not bound by the decision made by the lower court in Shirayama, it should have at least considered Shirayama because the case had ruled directly on the issue of compulsion. ${ }^{32}$ Second, by holding that the courts cannot compel parties to mediate but that parties can be strongly encouraged to mediate through the above-mentioned ADR order, the Court of Appeal in Halsey arguably contradicted itself.

\footnotetext{
25 ibid [2].

26 ibid [9] (Dyson LJ).

27 ibid [11] (Dyson LJ).

28 ibid [30] (Dyson LJ).

29 Blake, Browne, and Sime (n 1) 109.

${ }^{30}$ Halsey (n 24) [10] (Dyson LJ).

31 Masood Ahmed, 'Implied Compulsory mediation' (2012) 31 (2) Civil Justice Quarterly 151, 161.

32 ibid.
} 
This is because there is clearly an element of compulsion in the ADR order in the Commercial Court as if the case is not settled, parties are required to provide reasons as to why mediation was unsuccessful. Moreover, as Billingsley and Ahmed argue, 'It is highly unlikely that parties, even if they are opposed to ADR, will decline to abide by a court order: such parties would clearly face severe cost consequences under CPR Rule 44.3'. ${ }^{33}$ Therefore, while earlier postWoolf authorities such as Kinstreet and Shirayama recognised the courts' powers to order parties to mediate, Halsey unequivocally rejected that notion and stated that all the courts could do was encourage.

Adding to the state of confusion, soon after Dyson LJ's comments in Halsey, the court in $C v R H L$ ordered parties to mediate. ${ }^{34} C v R H L$ involved a claimant who sought an anti-suit injunction against the respondent to restrain the pursuit of proceedings in Russia which were allegedly in breach of an arbitration agreement contained in a share purchase agreement. Colman J ordered mediation and said that:

I have no doubt that the overall interests of all parties, including $R H L$ 's associated companies and beneficial owners, would be best served if the whole group of disputes between $C$ and $R H L$ was referred to mediation before any further substantial costs are incurred either in pursuing or defending satellite litigation such as this application or in pursuing the claim in the arbitration both for injunctive relief and for damages. In many respects this series of disputes with its particular commercial background is the paradigm of a case which is likely to be settled by mediation. ${ }^{35}$

The court in $C v R H L$ made an ADR order that went beyond the above-mentioned ADR order in the Commercial Court in regard to what it required parties to do. This is because the court's ADR order in $C v R H L$ required the parties to not only appoint a mediator within 28 days, but to also attend the mediation and provide to the mediator any evidence required and conclude the mediation by a specific date (27 May 2005 in the case). ${ }^{36}$ This appears to be a clear example of the court ordering parties to mediate and therefore contradicting Halsey's stance of rejecting compulsory mediation.

About a year and seven months after $C v R H L$, the Court of Appeal in Aird v Prime Meridian Ltd held a different view, ${ }^{37}$ namely that 'the court cannot, in the real world, compel

\footnotetext{
33 Billingsley and Ahmed (n 6) 10.

34 [2005] EWHC 873 (Comm).

35 ibid [8] (Colman J).

36 ibid [10] and [11] (Colman J).

37 [2006] EWCA Civ 1866; [2007] CP Rep 18 (Aird).
} 
a party who does not want to participate in a mediation' ${ }^{38}$ Aird involved an appeal against a ruling that an expert joint statement ordered for the purpose of mediation could not be used for any other purpose. The mediation between the two parties had failed and the appellant had sought to use the joint statement in the subsequent proceedings on the basis that it was ordered by the court pursuant to CPR r.35.12. However, the respondent argued that the joint statement was prepared for the purpose of mediation and was therefore privileged. The Court of Appeal allowed the appeal and held that the fact that the statement was prepared to be used in mediation was irrelevant on the basis that the court had no power to order mediation. ${ }^{39}$ May LJ stated that 'the court cannot order the parties to participate in mediation, neither can the court make orders stipulating the details of how the parties should conduct a mediation. The most the court can do is to encourage'. ${ }^{40}$ Therefore, May LJ in Aird rejected compulsory mediation and leaned towards Halsey's stance, that all the courts can do is encourage mediation.

Demonstrating the confusing state of affairs, about two years after the Court of Appeal's stance in Aird, the court in Honda Giken Kogyo Kabushiki Kaisha (A Firm) v Neesam dismissed the claimant's application for the hearing of two preliminary issues in the inquiry as to damages in a trademark infringement action and directed both parties to mediate. ${ }^{41}$ The court stated that:

In summary, then, I shall dismiss the application and direct that both parties use their best endeavours to ensure that a mediation is heard before the end of the Trinity term. I would like that to be recorded in the order that is to be made on this application. I would also wish the parties to report to the Court, through my clerk, in writing, on progress by 1st June 2009. Finally, 'best endeavours', as we know from best endeavours clauses in contracts, does not mean 'second best endeavours. ${ }^{42}$

Based on the above direction, it is arguable that the court in Honda was ordering the parties to not only engage in the mediation, but to also keep the court informed of their progress. It is therefore argued that the court's order in Honda directly contradicted the courts' positions in Halsey and Aird.

With the judiciary holding such contradictory views on mandatory mediation, it is not surprising that other courts have been reluctant to offer a definite answer to parties posing the

\footnotetext{
38 ibid [6] (May LJ).

${ }^{39}$ De Girolamo (n 4) 175.

${ }^{40}$ Aird (n 37).

41 [2009] EWHC 1213 (Pat); 2009 WL 1504398.

42 ibid [39] (Judge Fysh).
} 
question. For example, in $A B \&$ Ors $v$ Ministry of Defence, ${ }^{43}$ there were three applications before the court including one which asked the court to make an order requiring the parties to attempt to resolve the dispute by mediation. However, despite considering the parties' arguments and authorities such as Halsey on the question of whether the court is able to order mediation as opposed to merely encourage it, MacDuff $\mathrm{J}$ declined to provide a definite answer and stated that, "whether I have the power to order mediation or merely to encourage, I do not consider it would be helpful for me to put anything in my order'. ${ }^{44}$ It is argued that MacDuff J's decision in $A B$ to refuse to take a position on compulsory mediation further shows the confusion caused by diverging judicial views. ${ }^{45}$

Ward LJ's comments in the Court of Appeal decision of Wright v Michael Wright (Supplies) Ltd created more uncertainty in an already difficult area. ${ }^{46}$ Ward LJ was also one of the judges who presided in Halsey. Wright involved a dispute between two businessmen and the appeal was against the decision of the lower court to determine the matter without oral evidence. When commenting on the parties' unwillingness to mediate the dispute despite numerous pleas from the lower court to do so, Ward LJ stated that it was perhaps time to review the rule in Halsey on compulsion which provided that the courts cannot order unwilling parties to mediate, because to do so, would obstruct the parties' right of access to the courts. ${ }^{47}$ Ward LJ also appeared to suggest that CPR r.26.4(2)(b) gave the courts the power to direct a stay for mediation:

Does CPR r.26.4(2)(b) allow the court of its own initiative at any time, not just at the time of allocation, to direct a stay for mediation to be attempted, with the warning of the costs consequences, which Halsey did spell out and which should be rigorously applied, for unreasonably refusing to agree to ADR? Is a stay really "an unacceptable obstruction" to the parties right of access to the court if they have to wait a while before being allowed across the court's threshold? Perhaps some bold judge will accede to an invitation to rule on these questions so that the court can have another look at Halsey in the light of the past 10 years of developments in this field. ${ }^{48}$

\footnotetext{
43 [2009] EWHC 3516 (QBD); 2009 WL 5386981.

44 ibid [18] (MacDuff J).

45 De Girolamo (n 4) 176.

46 [2013] EWCA Civ 234; [2013] CP Rep 32.

47 ibid [3] (Ward LJ).

48 ibid.
} 
Ward LJ's comments recanted the rule in Halsey and indicated a change in judicial attitude towards compulsory mediation. ${ }^{49}$ Nevertheless, despite his comments, the courts recently appear to have reverted back to Halsey's position on compulsion as illustrated by $L a$ Porte and Christian v Commissioner of Police of the Metropolis. ${ }^{50}$ La Porte concerned a police commissioner who was found to have failed, without adequate justification, to engage in ADR which had a reasonable prospect of success. When applying Halsey to the facts, Turner $\mathbf{J}$ approved of Halsey and stated that the courts cannot compel parties to mediate, and the ADR order made in Admiralty and Commercial Court 'stops short of actually compelling the parties to undertake an ADR' ${ }^{51}$

As illustrated by the above decisions, there appears to be inconsistency among the judiciary regarding compulsory mediation. Earlier post-Woolf authorities such as Kinstreet and Shirayama not only recognised the courts' powers to order parties to mediate, but also exercised those powers. However, Halsey rejected that compulsion and held that the courts' powers were limited to encouraging parties to mediate. Halsey 'led to the emergence of an opposing judicial school of thought', ${ }^{52}$ where some courts ordered parties to mediate such as in $C v R H L$ and Honda, while others held the firm view that the courts could only encourage but not compel mediation such as in Aird and more recently, in La Porte. Other courts such as in $A B v$ Ministry of Defence refused to take a position despite the applicant in the case specifically asking for an answer on the issue. The courts' inconsistency on compulsory mediation has therefore resulted in a state of uncertainty especially for litigants who, as Billingsley and Ahmed argue, 'are left in the undesirable position of not knowing what approach the courts will take in deciding whether to mandate ADR'. ${ }^{53}$

\section{JUDICIAL UNCERTAINTY ON WHEN A REFUSAL TO MEDIATE IS UNREASONABLE}

The courts in England and Wales have the power under CPR r.44.2 to deprive a winning party of some or all of their costs if they find that the party's refusal to mediate was unreasonable. ${ }^{54}$ In deciding whether a party's refusal was unreasonable, the court will consider all the

\footnotetext{
${ }^{49}$ Masood Ahmed, 'Bridging the Gap between Alternative Dispute Resolution and Robust Adverse Costs Orders' (2016) 8 Contemporary Readings in Law and Social Justice 98, 108.

50 [2015] EWHC 371 (QB); [2015] 3 Costs LR 471.

51 ibid [30] (Turner J).

52 Billingsley and Ahmed (n 6) 11.

53 ibid 18.

54 Susan Blake, Julie Browne and Stuart Sime, The Jackson ADR Handbook (2nd edn, Oxford University Press 2016) 119.
} 
circumstances of the case including but not limited to the factors outlined by Dyson LJ in Halsey:

The question whether a party has acted unreasonably in refusing ADR must be determined having regard to all the circumstances of the particular case.... factors which may be relevant to the question whether a party has unreasonably refused ADR will include (but are not limited to) the following: (a) the nature of the dispute; (b) the merits of the case; (c) the extent to which other settlement methods have been attempted; (d) whether the costs of the ADR would be disproportionately high; (e) whether any delay in setting up and attending the ADR would have been prejudicial; and (f) whether the ADR had a reasonable prospect of success... 55

The courts' application of the Halsey factors has arguably 'created a body of divergent case law', ${ }^{56}$ particularly in relation to the following three issues: a party's intransigence, a party's silence in the face of an invitation to mediate and a party's belief in the merits of their case.

\section{A party's intransigence}

Nigel Witham Ltd $v$ Smith concerned the issue of whether a party's intransigence was a sufficient reason to justify a refusal to mediate. ${ }^{57}$ In Nigel, the case had been decided in favour of the defendants, with the claimant being expected to pay the defendants, a modest sum of $£ 1,683$. The costs incurred by both parties outweighed this sum. The main question before the court was whether it should depart from the normal costs principle (that the loser pays the winner's costs) and therefore make an adverse cost order against the defendants for various reasons, one of which was their failure to mediate. The claimants argued that the defendants 'failed to mediate until very late in the day, at a time when the majority of the costs had been incurred', ${ }^{58}$ and that this was 'unreasonable and should therefore be reflected in the costs order' ${ }^{59}$ HHJ Coulson QC applied the Halsey factors and concluded that an early mediation would have had little or no chances of success due to the claimant's intransigence and accordingly, it was not unreasonable for the defendants to refuse to mediate at an earlier stage. He stated:

I am not persuaded, even if the defendants had agreed to an early mediation, that it would have led to a settlement. The documents make plain that, at the very start of the dispute, $\mathrm{Mr}$

\footnotetext{
${ }^{55}$ Halsey (n 24) [16] (Dyson LJ).

${ }^{56}$ Masood Ahmed, 'Mediation: the need for a united, clear and consistent judicial voice: Thakkar $v$ Patel [2017] EWCA Civ 117; Gore v Naheed [2017] EWCA Civ 369' (2018) 37 (1) Civil Justice Quarterly 13, 14.

57 [2008] EWHC 12 (TCC); [2008] WL 168848.

58 ibid [30].

59 ibid.
} 
Witham had an extremely uncompromising attitude to the defendants and his claim against them. He informed the mediator that he was proposing that the first defendant was "a donkey" whom he had "under enormous pressure right now", and that the defendants were "the clients from hell". The claimant's pre-action correspondence is littered with references to its intentions to pursue an entitlement to every penny of the claim. Compromise and reconciliation do not feature prominently in the claimant's correspondence. As a result, in accordance with one of the key principles in Halsey, as noted in paragraph 8 above, I conclude that an early mediation had little or no chance of success. ${ }^{60}$

The court in Nigel therefore held the view that the claimant's intransigence meant the mediation 'would not have had a reasonable prospect of success', ${ }^{61}$ and was a sufficient reason to justify the defendants' refusal to an earlier mediation. However, the court in Rolfv De Guerin adopted a different position when dealing with the exact issue. ${ }^{62}$

Rolf concerned an appeal by the claimant against a costs order requiring her to pay the defendant's costs from the expiry of the time for accepting her Part 36 offer. The claimant had written to the defendant two letters suggesting settlement negotiations and had then made a Part 36 Offer to settle including a suggestion that the parties mediate their dispute. The defendant had refused to mediate until it was too late and stated that the claimant had been intransigent because she had declined their offer which was that they would not enforce their order for costs and the payment of $£ 2500$ against her, if she dropped the appeal. ${ }^{63}$ However, Rix LJ 'considered that explanation to be inadequate to prevent the court from marking the defendant's failure to respond by a special order as to costs of the appeal', ${ }^{64}$ and thus held that the defendant's refusal to mediate was unreasonable.

Therefore, while the court in Nigel held the view that a party's intransigence was a sufficient reason to justify the other party's refusal of an invitation to mediate, the Court of Appeal in Rolf, 'although having recognised that one of the parties was intransigent and mediation likely would not have resulted in settlement, found that to be an insufficient excuse'. ${ }^{65}$ It is therefore argued that these two cases illustrate a lack of judicial consistency.

\section{Silence in the face of an invitation mediate}

\footnotetext{
60 ibid [34] (HHJ Coulson QC).

61 ibid [36].

62 [2011] EWCA Civ 78; [2011] CP Rep 24.

63 ibid [42] (Rix LJ).

64 ibid.

${ }^{65}$ De Girolamo (n 4) 178.
} 
A party's silence in response to an offer to mediate was examined for the first time in PGF II SA v OMFS Co $1 \mathrm{Ltd},{ }^{66}$ in which the Court of Appeal answered the following question: "what should be the response of the court to a party which, when invited by its opponent to take part in a process of alternative dispute resolution (“ADR"), simply declines to respond to the invitation in any way?'. ${ }^{67}$ In this case, the claimant's written invitation to mediate the dispute had been met with complete silence by the defendant. ${ }^{68}$ Briggs LJ held that the defendant's silence had been unreasonable and stated that:

The time has now come for this court firmly to endorse the advice given in para 11.56 of the ADR Handbook, that silence in the face of an invitation to participate in ADR is, as a general rule, of itself unreasonable, regardless whether an outright refusal, or a refusal to engage in the type of ADR requested, or to do so at the time requested, might have been justified by the identification of reasonable grounds. I put this forward as a general rather than invariable rule because it is possible that there may be rare cases where ADR is so obviously inappropriate that to characterise silence as unreasonable would be pure formalism. There may also be cases where the failure to respond at all was a result of some mistake in the office, leading to a failure to appreciate that the invitation had been made, but in such cases the onus would lie squarely on the recipient of the invitation to make that explanation good. ${ }^{69}$

The Court of Appeal in PGF II SA therefore extended the Halsey factors by holding that as a general rule, a party's silence in the face of an invitation to mediate will be held unreasonable regardless of whether that party had a good reason for refusing. ${ }^{70}$ It is argued that by stating that cases in which silence would be acceptable because ADR was so obviously inappropriate are rare, the court was sending out 'an important message to civil litigants, requiring them to engage with a serious invitation to participate in ADR, even if they have reasons which might justify a refusal' ${ }^{71}$ However, about 6 months later, the court in $R$ (on the application of Paul Crawford) $v$ The University of Newcastle Upon Tyne held that the defendant's silence in response to requests to mediate was not unreasonable. ${ }^{72}$

$R$ (on the application of Paul Crawford) concerned a costs order dispute. The defendant was seeking payment of its costs while the claimant sought an order of 'no order as to costs'

\footnotetext{
66 [2013] EWCA Civ 1288; [2014] 1 WLR 1386 (PGF II SA).

67 ibid [1].

68 ibid [2].

69 ibid [34] (Briggs LJ).

${ }^{70}$ Louise Smail, 'When is silence unreasonable conduct?' (2014) Jan/Feb Construction Newsletter 3-4.

71 PGF II SA (n 67) [56] (Briggs LJ).

72 [2014] EWHC 1197; 2014 WL 1219668.
} 
on the basis of three reasons, one of which was the defendant's failure to engage in mediation when invited to do so by the claimant. ${ }^{73}$ The claimant relied on the Court of Appeal's decision in PGF II SA and contended that the defendant's failure to respond to the letters inviting them to mediate was itself unreasonable and justified making no order as to costs. ${ }^{74}$ In holding that that the defendant's silence was not unreasonable, the court stated that:

However, faced with the claimant pursuing the OIA procedure, I am not persuaded that, despite his chasing letters of 13 September 2012 and 15 October 2013, that the defendant's silence should be characterised as unreasonable and, in itself, suffices to deprive the defendant of all its costs. ${ }^{75}$

Based on the court's view, it could be argued that the reason why the defendant's silence was held not to be unreasonable in this case was because the parties were already engaged with another ADR process (the OIA procedure) and accordingly, it could not be said that the defendant had 'refused to engage with ADR' ${ }^{76}$ However, the difficulty with that argument is that the defendant in $R$ (on the application of Paul Crawford) had not relied on their participation in the OIA procedure as a justification for their refusal to respond to the claimant's offers to mediate. Therefore, there appears to be inconsistency between the stances adopted by the court in the two cases. As De Girolamo puts it, the court's decision in $R$ (on the application of Paul Crawford) is 'seemingly at odds with the facts in PGF II SA as the defendant here also ignored all requests for mediation and did not specifically point to the lack of need for mediation given its participation in the ombudsman process'. ${ }^{77}$

\section{The merits of the case}

The merits principle established in Halsey is the principle that a party's reasonable belief that he has a watertight case may be sufficient justification for a refusal to mediate. ${ }^{78}$ It is argued that the Court of Appeal's recent consideration of this principle in Thakkar v Patel, ${ }^{79}$ and Gore $v$ Naheed ${ }^{80}$ further illustrates the urgent need for clarity. ${ }^{81}$

\footnotetext{
73 ibid [12].

74 ibid [25].

75 ibid [74].

76 Blake, Browne, and Sime (n 55) 136.

77 De Girolamo (n 4) 179.

78 Tony Allen, Mediation Law and Civil Practice (2nd edn, Bloomsbury Professional 2019) 143.

79 [2017] EWCA Civ 117; [2017] 2 Costs LR 233 (Thakkar).

${ }^{80}$ [2017] EWCA Civ 369; [2017] 3 Costs LR 509 (Gore).

81 Ahmed (n 56) 18.
} 
Thakkar concerned 'an appeal against a costs order made in circumstances where a purported Part 36 offer had been withdrawn after 21 days and there had been a failure to mediate'. ${ }^{82}$ Both parties had expressed a willingness to mediate; 'The claimants were proactive in making arrangements for a mediation and identifying possible mediators for consideration by the defendants. The defendants, by contrast, were slow to respond to letters and raised all sorts of difficulties' ${ }^{83}$ The judge at the lower court considered the defendants' conduct in relation to mediation and after weighing up all the circumstances, he ordered the defendants to pay $75 \%$ of the claimant's costs. The defendants appealed against that order. In dismissing the appeal and holding that the defendants' behaviour of dragging their feet in relation to mediation had been unreasonable, Jackson LJ stated that:

The message which this court sent out in PGF II was that to remain silent in the face of an offer to mediate is, absent exceptional circumstances, unreasonable conduct meriting a costs sanction, even in cases where mediation is unlikely to succeed. The message which the court sends out in this case is that in a case where bilateral negotiations fail but mediation is obviously appropriate, it behoves both parties to get on with it. If one party frustrates the process by delaying and dragging its feet for no good reason, that will merit a costs sanction. In the present case, the costs sanction was severe, but not so severe that this court should intervene. ${ }^{84}$

By affirming PGF II SA and stating that where mediation is appropriate both parties should get on with it, it is arguable that the Court of Appeal in Thakkar did not view the merits principle as a sufficient reason for a party's refusal or reluctance to mediate. As Ahmed neatly puts it, ' $P G F$ and Thakkar sit uncomfortably with the merits principle because they make clear that a party who is invited to mediation will be obliged to constructively engage with that invitation regardless of that party's belief in the strengths of his case'. ${ }^{85}$ The Court in Thakkar was therefore sending out the message that an invitation to mediate should be seriously considered regardless of the merits of one's case. However, about 4 months later, the Court of Appeal in Gore 'took a completely divergent and inconsistent approach'. ${ }^{86}$

Gore was an appeal by the defendants against a costs order which provided that the defendants pay the claimant's costs. On appeal, the defendants contended that because of the

\footnotetext{
82 Thakkar (n 79).

83 ibid [10].

84 ibid [31] (Jackson LJ).

85 Ahmed (n 56) 16.

86 ibid 17.
} 
claimant's failure to engage with invitations to mediate the dispute, the judge in the lower court had erred in failing to deduct the claimant's costs in accordance with the guidance set out in PGF II SA. Patten LJ held that the judge in the lower court had not erred in concluding that it was not unreasonable for the claimant to have refused to mediate. He stated:

Mr McNae referred us to the decision of this court in PGF II SA v OMFS Company 1 Ltd in which Briggs LJ emphasised the need, as he saw it, for the courts to encourage parties to embark on ADR in appropriate cases and said that silence in the face of an invitation to participate in ADR should, as a general rule, be treated as unreasonable regardless of whether a refusal to mediate might in the circumstances have been justified. Speaking for myself, I have some difficulty in accepting that the desire of a party to have his rights determined by a court of law in preference to mediation can be said to be unreasonable conduct particularly when, as here, those rights are ultimately vindicated. But, as Briggs LJ makes clear in his judgment, a failure to engage, even if unreasonable, does not automatically result in a costs penalty. It is simply a factor to be taken into account by the judge when exercising his costs discretion. ${ }^{87}$

Patten LJ's statements arguably contradicted the Court of Appeal's earlier stances in PGF II SA and Thakkar, namely that parties should seriously engage with an invitation to mediate regardless of their belief in the merits of their case. By adopting different stances, the Court of Appeal has arguably created a state of uncertainty for both litigants and judges of the lower courts as evidenced by the findings of the recently published Civil Justice Council (CJC) ADR Working Group Final Report. The Final Report revealed that:

There was regret that the precise guidance from the Court of Appeal had become somewhat confused and in particular that between the PGF II SA and Gore v Naheed decisions it was difficult to determine a common thread. The Council of Circuit Judges referred to the need for clarity over costs sanctions and guidance. ${ }^{88}$

As illustrated by the above cases, 'another level of inconsistency and uncertainty is found in the way the courts have opined on decisions taken by parties who refuse to attend on mediation when requested by the other party'. ${ }^{89}$ This inconsistency is shown by the court's divergent application of the Halsey factors, particularly in relation to the treatment of three

\footnotetext{
${ }^{87}$ Gore (n 80) [49] (Patten LJ).

${ }^{88}$ Civil Justice Council (CJC), Final Report on the future role of ADR (Alternative Dispute Resolution) in Civil Justice (CJC November 2018) para 4.25.

${ }^{89}$ De Girolamo (n 4) 177.
} 
issues; a party's intransigence, a party's silence in the face of an invitation to mediate and a party's belief in the merits of their case.

As seen above, the court in Nigel stated that a party's intransigence was a sufficient reason to justify a refusal to mediate as it meant that the mediation would not have had a reasonable prospect of success while the court in Rolf held the contrary view. The Court of Appeal in PGF II SA held that silence in the face of an invitation to mediate, as a general rule, is itself unreasonable while the court in $R$ (on the application of Paul Crawford) held that the party's silence to letters inviting them to mediate was not unreasonable. Perhaps what has caused the most uncertainty is the court's treatment of the merits principle which Ahmed describes to be 'a further difficulty within the ADR jurisprudence' ${ }^{90}$

This is best demonstrated by the recent Court of Appeal decisions of Thakkar and Gore. In Thakkar, the Court of Appeal sent out a clear message that in cases where negotiations fail but mediation is obviously appropriate, both parties should get on with it regardless of either party's belief in the merits of their case. However, a mere 4 months later, the Court of Appeal in Gore stated that the desire of a party to litigate their dispute rather than mediate could not be said to be unreasonable conduct especially if that party ends up winning in court.

It is argued that these mixed messages have left practitioners and mediators confused on the court's approach to mediation. For example, when commenting on how the Court of Appeal in Thakkar and Gore dealt with parties not responding to offers to mediate, Watkinson opined that 'the exercise of judgement when such an offer is made, and how it is responded to, remains as tricky as ever'. ${ }^{91}$ Additionally, Greenwood recently stated that the lesson to be learned by parties from Thakkar and Gore is 'you will never know which way the court will turn so it safer to mediate', ${ }^{92}$ while Muscutt said that 'it is difficult to reconcile these two Court of Appeal judgments'. ${ }^{93}$ There is therefore a need for clarity for lawyers and most importantly, for parties. As De Girolamo sums it up, 'the responding party is placed in a quandary: should

\footnotetext{
90 Ahmed (n 56) 14.

91 David Watkinson, 'The Court of Appeal speaks again: Gore v Naheed' Garden Court Mediation (26 June 2017) < www.gardencourtmediation.co.uk/the-court-of-appeal-speaks-again-gore-v-naheed/ > accessed 30 June 2019.

92 Victoria Greenwood, 'My case is solid - do I still need to mediate? A case law update' NW Mediation Solutions (17 January 2019) <www.nwmediationsolutions.co.uk/blog/my-case-is-solid-do-i-still-need-to-mediate-a-caselaw-update > accessed 30 June 2019.

93 Francesa Muscutt, 'Mediate or face cost consequences - is this still the court's approach' DAC BEACHCROFT (15 March 2018) <www.dacbeachcroft.com/en/gb/articles/2018/march/mediate-or-face-cost-consequences-isthis-still-the-court-s-approach/ > accessed 30 June 2019.
} 
it go to mediation and what are the consequences of refusing. The consequences should be clear at the outset of the decision, not at the end when costs are being assessed and stakes are high'. ${ }^{94}$

\section{E. ADDRESSING ARGUMENTS AGAINST COMPULSORY MEDIATION}

Before proposing a framework aimed at addressing the problems set out above, it is worth briefly responding to the common arguments made by critics of compulsory mediation. Majority argue that compulsory mediation violates the voluntary nature of the process, breaches Article 6 of the European Convention on Human Rights (ECHR) and is not effective for parties unwilling to mediate and will therefore only result in increased costs. ${ }^{95}$ Each of these arguments will be addressed below.

\section{Voluntary nature of the process}

Critics of compulsory mediation such as Quek argue that compelling parties to mediate would undermine the voluntariness of the process. ${ }^{96}$ Other commentators have gone as far as stating that 'when mediation is imposed, its virtues are lost'.${ }^{97}$ In addition, the court in Halsey stated that even if the court had jurisdiction to order unwilling parties to mediate, it would find it difficult to exercise that power and would instead adopt the following statement provided by the editors of Civil Procedure 2003, 'the hallmark of ADR procedures, and perhaps the key to their effectiveness in individual cases, is that they are processes voluntarily entered into by the parties in dispute with outcomes, if the parties so wish, which are non-binding'. ${ }^{98}$

In response, it is argued that compulsory mediation does not violate the voluntary nature of the process because there is a clear distinction between compelling parties to participate in a mediation and compelling them to reach a settlement. The latter breaches the voluntary nature of the process but not the former. As Dawson neatly puts it, in a compulsory mediation scheme 'settlement is and will always remain voluntary'. ${ }^{99}$ Furthermore, compulsion to mediate and compulsion to settle is not only conceptually different, but also appears distinct in practice. ${ }^{100}$ This is evidenced by the fact that 'studies have shown that rates of settlement do not show any

\footnotetext{
94 De Girolamo (n 4) 181.

95 Daniel Kaufman Schaffer, ‘An examination of mandatory court-based mediation' (2018) 84 (3) Arbitration $229,235-236$.

96 Dorcas Quek, 'Mandatory Mediation: An Oxymoron? Examining the Feasibility of Implementing a CourtMandated Mediation Program’ (2010) 11 Cardozo Journal of Conflict Resolution 479, 484-485.

97 Katherine Stylianou, ‘Compulsory mediation' (2018) 48 (Jan) Family Law 112.

98 Halsey (n 24) [9].

99 Brian Dawson, 'Unwanted Intervention' (2014) 164 New Law Journal 1, 2.

100 Julian Sidoli del Ceno, 'Compulsory mediation: civil justice, human rights and proportionality' (2014) 6 International Journal of Law in the Built Environment 286, 290.
} 
real difference, irrespective of whether the participants entered the process voluntarily or were compelled to do so'. ${ }^{101}$ It is therefore submitted that the introduction of an express rule providing the courts with the powers to compel parties to mediate would not violate or contradict the voluntary nature of mediation.

\section{Article 6 of the ECHR}

The second argument commonly shared among those opposed to compulsory mediation is the notion that compulsory mediation obstructs a party's right to access the courts and accordingly breaches Article 6 of the ECHR. ${ }^{102}$ Article 6 provides that 'everyone is entitled to a fair and public hearing within a reasonable time by an independent and impartial tribunal established by law'. ${ }^{103}$ This Article 6 argument stemmed from Dyson LJ's statements in Halsey:

[I]t seems to us that to oblige truly unwilling parties to refer their disputes to mediation would be to impose an unacceptable obstruction on their right of access to the court... [I]t seems to us likely that compulsion of ADR would be regarded as an unacceptable constraint on the right of access to the court and, therefore, a violation of article $6 .{ }^{104}$

Dyson LJ's statements were later approved by Briggs LJ by in PGF II SA who stated that compelling parties to mediate would 'risk contravening article 6'. ${ }^{105}$

Contrary to the above views, it is argued that compulsory mediation does not breach Article 6 of the ECHR because parties who are compelled to mediate would still access the courts if they wish to do so as mediation would not substitute the courts. The most that compulsory mediation would result in, is a short delay. ${ }^{106}$ Furthermore, as Blake, Browne and Sime argue, 'a compulsory order to attempt ADR might not even result in a delay in the trial process because the litigation timetable does not need to stayed or extended in most cases to accommodate ADR...? ${ }^{107}$

The argument that compulsory mediation would not infringe Article 6 of the ECHR is further supported by the decision in Rosalba Alassini and others v Telecom Italia SpA and others. ${ }^{108}$ In this case, the European Court ruled that Italian law which provided that parties who did not first attempt to mediate their dispute would forfeit their right to commence legal

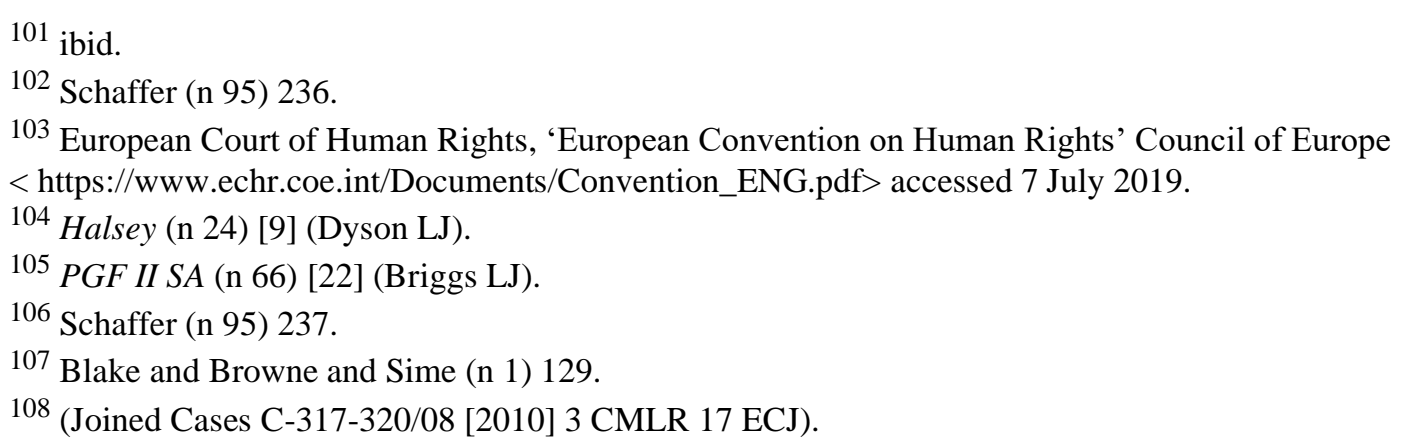


proceedings did not breach Article 6 of the ECHR. It is also worth noting that in light of the Alassini decision, Dyson LJ later recanted his position and accepted that in and of itself compulsory mediation does not breach article 6'. ${ }^{109}$ It is therefore submitted that the introduction of an express rule providing the courts with the power to compel parties to mediate would not breach Article 6 of the ECHR because parties can abandon the mediation at any time and proceed to court. As Dawson puts it, 'in the event that a settlement is not achieved the parties can and will carry on to trial'. ${ }^{110}$

\section{Parties unwilling to mediate and increased costs}

The third argument commonly advanced by those against compulsory mediation is that it is ineffective where parties are unwilling to mediate and will therefore only result in increased costs. ${ }^{111}$ This argument is best summed up by the following quote from Lord Dyson's talk at the CIArb Third Mediation Symposium: 'if the court were to compel parties into mediation to which they objected, that would achieve nothing except to add to the cost to be borne by both parties'. ${ }^{112}$

It is argued that that argument is not persuasive for five main reasons. Firstly, the unwillingness of one party or both parties is an issue that mediators are well equipped to deal with so that it does not hinder settlement efforts. Secondly, there is empirical data that proves that parties who are unwilling to mediate and are forced to do so may end up finding the process beneficial regardless of the compulsion. ${ }^{113}$ Thirdly, as Koo neatly puts it, 'no empirical data suggest that mediation fees in England and Wales are generally at the high end of the scale. Mediation fees assumed by one party with no financial concerns and pro bono mediation are not unheard of ${ }^{114}$ Fourthly, even if both parties are not willing to settle, the mediation process will likely result in a narrowing of issues which will save costs for both parties if they end up proceeding to trial. For example, Dawson, a mediator, states that 'I cannot recall a failed mediation (and there have been very few) where the issues were not narrowed down considerably, resulting in less expense going forward'. ${ }^{115}$ Fifthly, the lack of choice will

\footnotetext{
${ }^{109}$ Lord Dyson, Justice: Continuity and Change (Hart Publishing 2018) 382.

110 Dawson (n 99) 2.

111 Billingsley and Ahmed (n 6) 12.

112 Lord Dyson, 'A Word on Halsey v Milton Keynes' (2011) 77 (3) Arbitration: The International Journal of Arbitration, Mediation and Dispute Management 337, 338.

113 Schaffer (n 95) 237.

114 Anna KC Koo, 'Ten years after Halsey’ (2015) 34 (1) Civil Justice Quarterly 77, 80.

115 Dawson (n 99) 2.
} 
arguably result in both parties making the most out of the process in order to avoid wasting time and money.

It is therefore argued that the common arguments made against compulsory mediation, namely that it violates the voluntary nature of mediation, breaches Article 6 of the ECHR and will achieve nothing for parties unwilling to mediate except increase costs, are not persuasive. This is because under a compulsory mediation scheme, settlement will always remain voluntary thus upholding the voluntary nature of mediation and a party's right to access the courts under Article 6 of the ECHR. In addition, as previously discussed, even if a settlement is not reached, mediation will still benefit both parties as it will likely result in the issues being narrowed down significantly and thus save costs going forward.

\section{F. PROPOSED FRAMEWORK: IMPLEMENTING EXPRESS COMPULSORY MEDIATION}

\section{Summing up the problem}

As seen above, diverging judicial stances on compulsory mediation have resulted in a state of uncertainty and confusion. The courts in Shirayama, Kinstreet, $C \vee R H L$ and Honda ordered parties to mediate while the courts in Halsey, Aird and La Porte decided that they had no power to compel parties to mediate and that their role was limited to encouraging mediation.

In addition, the courts have also been inconsistent in applying the Halsey factors when deciding whether a party's refusal to mediate is unreasonable. This inconsistency is illustrated by the court's treatment of three factors: a party's intransigence, a party's silence in the face of an invitation to mediate and a party's belief in the merits of their case. As previously discussed, the court in Nigel found a party's intransigence to be a sufficient reason to justify a refusal to mediate while the Court of Appeal in Rolf held the contrary view. Similarly, the court in PGF II SA stated that silence in the face of an invitation to mediate is in itself unreasonable while the court in $R$ (on the application of Paul Crawford) held that the Defendant's silence was not unreasonable.

Moreover, the recent Court of Appeal decisions of Thakkar and Gore illustrate the confusing state of affairs. In Thakkar, the Court of Appeal stated that parties should seriously engage with invitations to mediate regardless of their belief in the merits of the case in order to avoid cost sanctions while a few months later, the Court of Appeal in Gore sent out a very different message. As previously discussed, these mixed messages have left litigants, lawyers and judges confused as evidenced by the findings of the (CJC) ADR Working Group Final Report. 
It is therefore submitted that there is an urgent need for clarity regarding compulsory mediation in England and Wales.

\section{Proposed framework}

It is submitted that the best way of remedying the existing state of uncertainty is to make mediation expressly compulsory for civil disputes. It is further argued that this would not be a drastic solution because it would simply be acknowledging a power already exercised by the courts. There are several ways of incorporating an express compulsory mediation scheme into the civil justice system. For instance, Lord Clarke proposed making mediation 'an integral part of standard directions'. ${ }^{116}$ He suggested:

How might this happen? It seems to me that the court has sufficient powers at present routinely to direct the parties to take part in a mediation process or attend a mediation hearing during the course of the pre-trial stage of any proceedings. I think of it like this. It could not be seriously argued that the case management judge could not direct the parties, say, to meet in the first week in June in order to discuss settlement. I would like to see such a direction as routine if it is not already routine. ${ }^{117}$

Lord Clarke further explained that the court's power to direct parties to mediate already exists as a case management power under Civil Procedure Rule (CPR) r.1.4(2)(e) which requires the courts to actively manage cases by 'encouraging parties to use an alternative dispute resolution (GL) procedure if the court considers that appropriate and facilitating the use of such procedure'. ${ }^{118}$ Accordingly, Lord Clarke's approach will not require an amendment of the current CPR rules. ${ }^{119}$ However, it is argued that Lord Clarke's approach fails to address the problems highlighted above specifically under part B, regarding the uncertainty on whether the courts can compel parties to mediate. This is because the current CPR rules do not expressly acknowledge the courts' powers to order parties to mediate even though the courts have exercised that power.

It is therefore suggested that the best way of integrating express compulsory mediation into the civil justice system is by amending the current CPR rules, specifically CPR r.1.4(2)(e), to make it clear that the courts in England and Wales have a discretionary power to order parties to mediate. It is further proposed that the courts should exercise this power either at the allocation stage or at the first case management conference in order to facilitate early settlement

\footnotetext{
${ }^{116}$ Anthony Clarke, 'The future of civil mediation' (2008) 74 (4) Arbitration 419, 423.

117 ibid 422.

118 CPR r.1.4(2)(e).

119 Ahmed (n 31) 172.
} 
and consequently save time and costs. If the parties ordered to mediate engage in a mediation but fail to settle, they should go on to litigate their dispute without fear of adverse cost sanctions at the end of the trial. Similarly, if the court does not order parties to mediate at the allocation stage or at the first case management conference, both parties can proceed to trial without facing cost sanctions at the end of the trial for not engaging in voluntary mediation.

It is argued that this approach would clear up the existing uncertainty surrounding the courts' powers to compel parties to mediate because as Billingsley and Ahmed neatly put it, 'it confirms the court's powers and thereby avoids parties and their lawyers "guessing" whether a court can order them to participate in ADR'. ${ }^{120}$ This approach would also clear up the uncertainty regarding the application of the Halsey factors because a party's refusal to participate in voluntary mediation would not be penalised. What would be penalised in costs, is a party's refusal to comply with a court order compelling them to mediate. More importantly, this approach would also ensure that mediation is only ordered for appropriate disputes unlike an approach that would require parties in all civil disputes to attempt mediation before going to trial. Such an approach would also not oblige parties to settle.

A good example of a provision expressly authorising a court to order parties to mediate is part 4 (26) of the Australian Civil Procedure Act 2005 (New South Wales) which stipulates that:

If it considers the circumstances appropriate, the court may, by order, refer any proceedings before it, or part of any such proceedings, for mediation by a mediator, and may do so either with or without the consent of the parties to the proceedings concerned. ${ }^{121}$

\section{G. Conclusion}

The aim of this article was to argue that mediation should be made expressly compulsory for civil disputes in England and Wales in order to clear up the uncertainty on whether the courts have the power to compel parties to mediate and on when a party's refusal to mediate will be found unreasonable. This aim has arguably been achieved as demonstrated by how diverging judicial stances have resulted in a state of confusion for lawyers and litigants. Moving forward, it is suggested that to remedy the existing uncertainty, the CPR rules should be amended to

\footnotetext{
${ }^{120}$ Billingsley and Ahmed (n 6) 20.

${ }^{121}$ New South Wales Government, 'Civil Procedure Act 2005 No 28' NSW legislation <https://www.legislation.nsw.gov.au/\#/view/act/2005/28/part4> accessed 4 August 2019.
} 
introduce a clear rule similar to the above Australian provision that expressly authorises the courts to compel parties to mediate where appropriate. 